\title{
Aerobic Exercise Protects Retinal Function and Structure from Light-Induced Retinal Degeneration
}

\author{
Eric C. Lawson, ${ }^{1,2}$ Moon K. Han, ${ }^{2}$ Jana T. Sellers, ${ }^{1}$ Micah A. Chrenek, ${ }^{1}$ Adam Hanif, ${ }^{2}$ Marissa A. Gogniat, ${ }^{2}$ \\ Jeffrey H. Boatright, ${ }^{1}$ and Machelle T. Pardue ${ }^{1,2}$ \\ ${ }^{1}$ Department of Ophthalmology, Emory University School of Medicine, Atlanta, Georgia 30322, and 2Rehab R\&D Center, Atlanta Veterans Administration \\ Medical Center, Decatur, Georgia 30033
}

\begin{abstract}
Aerobic exercise is a common intervention for rehabilitation of motor, and more recently, cognitive function (Intlekofer and Cotman, 2013; Wood et al., 2012). While the underlying mechanisms are complex, BDNF may mediate much of the beneficial effects of exercise to these neurons (Ploughman et al., 2007; Griffin et al., 2011; Real et al., 2013). We studied the effects of aerobic exercise on retinal neurons undergoing degeneration. We exercised wild-type BALB/c mice on a treadmill $(10 \mathrm{~m} / \mathrm{min}$ for $1 \mathrm{~h})$ for $5 \mathrm{~d} /$ week or placed control mice on static treadmills. After 2 weeks of exercise, mice were exposed to either toxic bright light (10,000 lux) for $4 \mathrm{~h}$ to induce photoreceptor degeneration or maintenance dim light (25 lux). Bright light caused $75 \%$ loss of both retinal function and photoreceptor numbers. However, exercised mice exposed to bright light had 2 times greater retinal function and photoreceptor nuclei than inactive mice exposed to bright light. In addition, exercise increased retinal BDNF protein levels by $20 \%$ compared with inactive mice. Systemic injections of a BDNF tropomyosin-receptor-kinase (TrkB) receptor antagonist reduced retinal function and photoreceptor nuclei counts in exercised mice to inactive levels, effectively blocking the protective effects seen with aerobic exercise. The data suggest that aerobic exercise is neuroprotective for retinal degeneration and that this effect is mediated by BDNF signaling.
\end{abstract}

Key words: retinal degeneration; exercise; photoreceptors; brain-derived neurotrophic factor; neuroprotection; treadmill

\section{Introduction}

Aerobic exercise is protective and rehabilitative in neurodegenerative diseases of the CNS and PNS. In rodents, aerobic exercise promotes neuron survival and axon regeneration after nerve transection (Ploughman et al., 2007; Wood et al., 2012), stimulates CNS neurogenesis (van Praag et al., 1999; Vessal and Darian-Smith, 2010), and improves memory and learning (Anderson et al., 2000; Radák et al., 2001). In humans, improvements in cognitive function have been observed in Alzheimer's patients (Intlekofer and Cotman, 2013; Vreugdenhil et al., 2012), along with improvements in nonmotor function in both Parkinson's disease (Filippin et al., 2010; Cruise et al., 2011) and amyotrophic lateral sclerosis patients (McCrate and Kaspar, 2008) when exposed to varying exercise regimens. Aerobic exercise also en-

Received May 15, 2013; revised Nov. 15, 2013; accepted Dec. 10, 2013.

Author contributions: E.C.L., J.H.B., and M.T.P. designed research; E.C.L., M.K.H., J.T.S., M.A.C., and M.A.G. performed research; E.C.L., J.T.S., M.A.C., A.H., J.H.B., and M.T.P. analyzed data; E.C.L., J.H.B., and M.T.P. wrote the paper.

This work was supported by National Institutes of Health Grants P30 EY006360 and NIH R01 EY014026-07S1 and the Abraham J. \& Phyllis Katz Foundation (to J.H.B.), Rehabilitation Research and Development Service Veterans Affairs Research Career Scientist Award (to M.T.P.), Atlanta Veterans Administration Center of Excellence in Vision and Neurocognitive Rehabilitation, and Departmental Award from Research to Prevent Blindness. We thank Arthur W. English for his advice on rodent exercise training, Dr. Joe Nocera for discussions on human exercise, and Dr. William Delaune for statistic advice.

The authors declare no competing financial interests.

Correspondence should be addressed to either of the following: Dr. Machelle T. Pardue, Atlanta Veterans Administration Medical Center, Research Service (1510ph), 1670 Clairmont Road, Decatur, GA 30033, E-mail: mpardue@emory.edu; or Jeffrey H. Boatright, Department of Ophthalmology, Emory University School of Medicine, 1365B Clinic B, Clifton Road, Atlanta, GA 30322, E-mail: jboatri@emory.edu.

DOI:10.1523/JNEUROSCI.2062-13.2014

Copyright $\odot 2014$ the authors $\quad 0270-6474 / 14 / 342406-07 \$ 15.00 / 0$ hances cognitive function in healthy aged and young individuals, suggesting a role in neuronal structure maintenance (Chaddock et al., 2010; Erickson et al., 2011; Intlekofer and Cotman, 2013). BDNF may mediate the beneficial effects of exercise. Systemic (Griffin et al., 2011) and local (Ploughman et al., 2007) BDNF levels increase after exercise, and disruption of BDNF signal transduction cascades precludes exercise effects (Real et al., 2013).

Aerobic exercise has been reported to be protective in the hippocampus (Intlekofer and Cotman, 2013), peripheral nerve axons (Sabatier et al., 2008, 2011; Wood et al., 2012), and more recently areas within the cerebral cortex (Vessal and DarianSmith, 2010). Here we tested whether aerobic exercise has a similar protective effect on retinal neurons, by running mice on a treadmill before and after light-induced retinal degeneration (LIRD). LIRD is a commonly used retinal degeneration model (Noell et al., 1966; Organisciak and Vaughan, 2010) that shares molecular, cellular, and functional phenotypes of photoreceptor cell death with leading causes of vision loss: age-related macular degeneration and retinitis pigmentosa (Remé et al., 2003; Organisciak and Vaughan, 2010). In addition, LIRD provides a retinal-specific injury to isolate the potential beneficial effects of aerobic exercise on retinal neurons and test whether the protective effects are mediated by BDNF.

\section{Materials and Methods}

Subjects. All animal procedures were approved by the Atlanta Veterans Administration Institutional Animal Care and Use Committee and conform to the standards of the Association for Research in Vision and Ophthalmology. We purchased male BALB/c mice from The Jackson Laboratory $(\mathrm{BALB} / \mathrm{cJ})$ and Charles River (BALB/cAnNCrl) and housed them under 12:12 light:dark cycle with ad libitum standard mouse chow. 


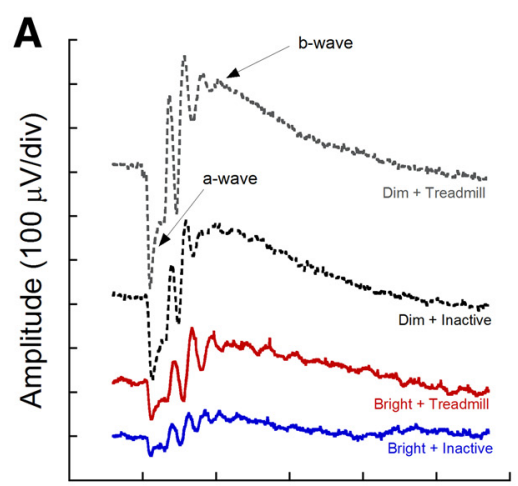

Time (10 ms/div)
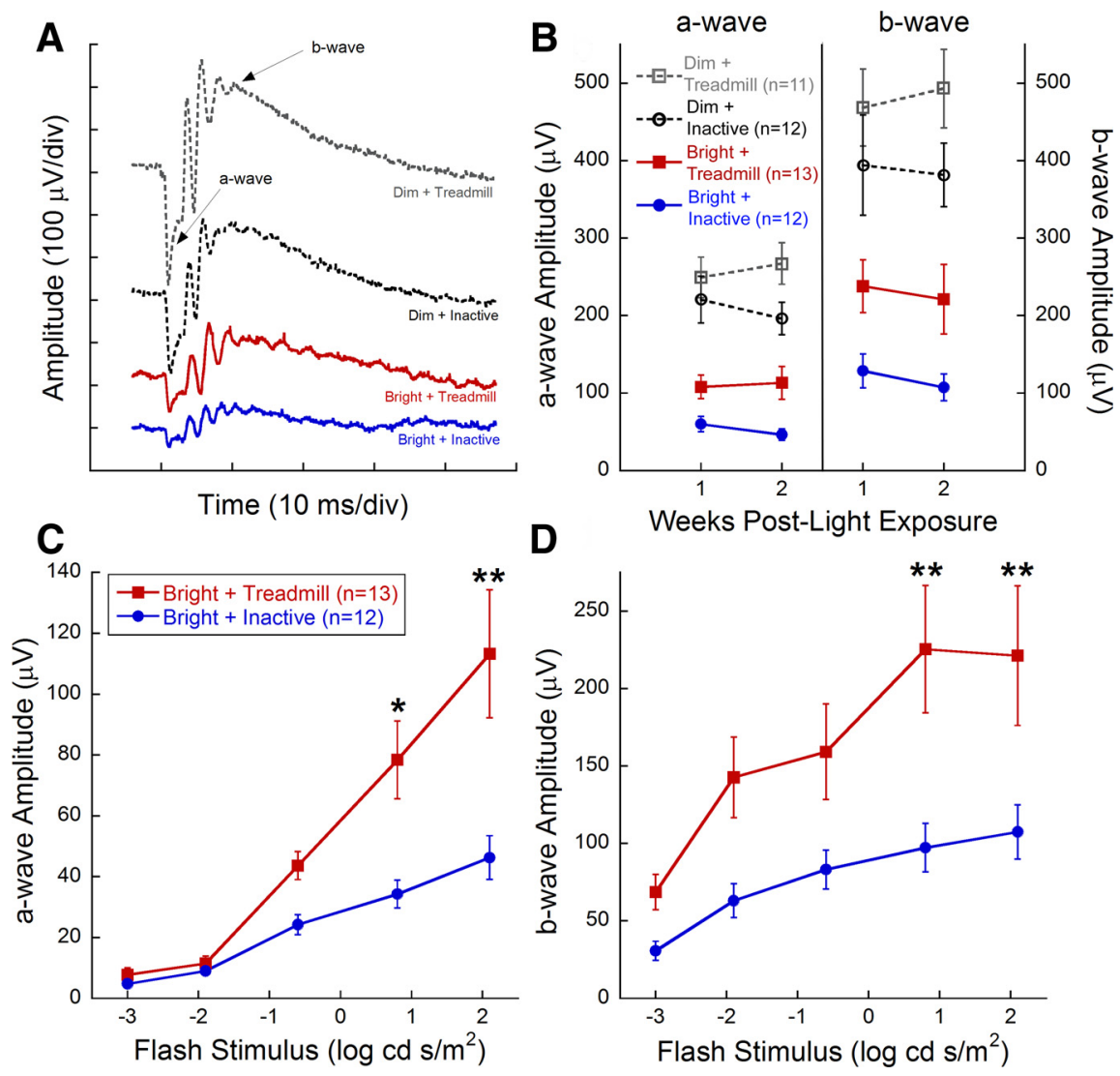

Figure 1. Aerobic exercise protects retinal function after light exposure. $\boldsymbol{A}$, Representative ERG waveforms from the brightest flash stimulus $\left(2.1 \log \mathrm{cd} \mathrm{s} / \mathrm{m}^{2}\right)$. B, Maximum a- and b-wave amplitudes did not diminish between 1 and 2 weeks after light exposure. Stimulus response curves at 2 weeks after light exposure for dark-adapted a-wave $(\boldsymbol{C})$ and b-wave $(\boldsymbol{D})$ amplitudes. Bright + Treadmill-treated mice (red) had significantly greater amplitudes at 0.8 and $2.1 \log \mathrm{cd} \mathrm{s} / \mathrm{m}^{2}$ compared with Bright + Inactive mice (blue) for both the a-wave and b-wave (two-way repeated-measures ANOVA; a-wave, $F_{(3,239)}=14.896, p<0.001$; $b$-wave, $\left.F_{(3,239)}=8.759, p<0.001\right)$, indicating preservation of photoreceptor and inner retinal function. Values are mean \pm SEM. Holm-Sidak post hoc comparisons: ${ }^{*} p<0.05,{ }^{* *} p<0.003$.

Treadmill exercise and light exposure regimen. We randomly assigned adult BALB/cJ mice into 4 treatment groups: Dim + Inactive $(n=12)$, Dim + Treadmill $(n=11)$, Bright + Inactive $(n=12)$, and Bright + Treadmill $(n=13)$. We exercised mice on a rodent treadmill with shock detection (Exer-3/6, Columbus Instruments). Based on previously reported methods, mice were exercised $5 \mathrm{~d}$ per week for $60 \mathrm{~min}$ each day at a rate of $10 \mathrm{~m} / \mathrm{min}$ (Wood et al., 2012). Mice received a maximum of 10 shocks $(1 \mathrm{~Hz}, 0.46 \mathrm{~mA})$ during the training session if they did not remain on the treadmill. All mice in this study quickly learned to train on the treadmill within the first week of testing and received $<1$ shock/week for the remaining experimental period. "Inactive" mice were handled identically to their treadmill-trained cohorts with the exception that their treadmills were stationary. After 2 weeks of pretreatment exercise, we exposed mice to $4 \mathrm{~h}$ of 10,000 lux (bright condition) or $25 \mathrm{lux}$ (dim condition) light using an LED light panel (LED500A, Fancierstudio) fitted to a standard mouse cage (Boatright et al., 2006). After light exposure, mice were exercised for 2 additional weeks as described above.

BDNF protein quantification. $\mathrm{BALB} / \mathrm{cAnNCrl}$ mice were exercised for nine consecutive days for $60 \mathrm{~min}$ at $10 \mathrm{~m} / \mathrm{min}$ on treadmills. Littermates were treated identically, but treadmills were stationary. Immediately after the ninth exercise session, mice were killed and retina, brain, and serum collected for BDNF ELISA analysis. Brains were dissected to isolate the hippocampus for further analysis. Hippocampus and retina were lysed using stainless steel beads, a vortex homogenizer, and ELISA lysis buffer (137 mm NaCl, 20 mm Tris-HCl, pH 8.0, 1\% IGEPAL, and 10\% glycerol, with Complete Protease Inhibitor, (Roche). Insoluble material was removed by centrifugation.
We determined BDNF protein levels by ELISA (Promega, BDNF $\mathrm{E}_{\max }$ Immunoassay System) based on the manufacturer's instructions. A plate reader was used to measure absorbance at $450 \mathrm{~nm}$ (BioTek ELx808), and absorbance values were compared with an internal standard curve on the same plate.

BDNF TrkB antagonist injections. We randomly divided adult BALB/c mice (both BALB/ cAnNCrl and BALB/cJ in two cohorts) into seven treatment groups: Bright + Inactive + Vehicle $(n=9)$, Bright + Inactive + ANA-12 $(n=10)$, Bright + Treadmill + Vehicle $(n=$ $9)$, Bright + Treadmill + ANA-12 $(n=9)$, Dim + Treadmill + Vehicle $(n=4)$, Dim + Treadmill + ANA-12 $(n=2)$, and Dim + Inactive + Vehicle $(n=5)$. We performed intraperitoneal injections of ANA-12 $(0.5 \mathrm{mg} / \mathrm{kg}$ body weight) or vehicle (1\% DMSO, 16.5\% Cremophor EL, Sigma C5135-500G; 16.5\% ethanol, 66\% Dulbecco's PBS, pH 7.4) using a volume of $4 \mu \mathrm{l} / \mathrm{g}$ body weight. ANA-12 is highly selective for binding and inactivating TrkB versus TrkA or TrkC and readily crosses the blood-brain barrier after systemic administration (Cazorla et al., 2011; Spaeth et al., 2012; Vassoler et al., 2013). Based on a detailed characterization of ANA-12 pharmacokinetics (Cazorla et al., 2011), we injected mice $2.5 \mathrm{~h}$ before each treadmill training session to align peak TrkB inhibition with exercise. Mice were exercised for 2 weeks before light exposure and 1 week after exposure ( $5 \mathrm{~d}$ per week for $60 \mathrm{~min}$ at 10 $\mathrm{m} / \mathrm{min}$ ). We measured retinal function and processed eyes for morphological analysis at 1 week after experimental light exposure. Data were normalized to maximal values for each cohort to combine data across substrains from different vendors.

Electroretinography (ERG). At 1 and 2 weeks after light exposure, we measured retinal function using ERG as previously detailed (Mocko et al., 2011). Briefly, mice were dark-adapted overnight; and under dim red light, we anesthetized [ketamine $(80 \mathrm{mg} / \mathrm{kg}) / x y l a z i n e ~(16 \mathrm{mg} / \mathrm{kg})]$ the mice, anesthetized the corneas ( $1 \%$ tetracaine), and dilated the pupils ( $1 \%$ tropicamide, $1 \%$ cyclopentolate). We maintained body temperature at $37^{\circ} \mathrm{C}$ using a heating plate (ATC 1000 ; World Precision Instruments). ERG stimuli consisted of a 5-step full-field flash stimuli presented by a Ganzfeld dome under scotopic conditions $\left(-3.0\right.$ to $\left.2.1 \log \mathrm{cd} \mathrm{s} / \mathrm{m}^{2}\right)$. Interflash interval increased with flash stimulus from 2 to $70 \mathrm{~s}$. The electrical response of the retina was recorded using a gold wire contacting the cornea through a layer of $1 \%$ methylcellulose. We referenced and grounded the responses to $1 \mathrm{~cm}$ platinum needle electrodes inserted subcutaneously in the cheek and tail, respectively. Responses were acquired on a commercial ERG system (UTAS 3000, LKC Technologies). After testing, we administered yohimbine $(2.1 \mathrm{mg} / \mathrm{kg})$ to the mice to reverse effects of xylazine and prevent corneal ulcers (Turner and Albassam, 2005).

The a-wave, which originates in the photoreceptors (Penn and Hagins, 1969; Hood and Birch, 1990), was measured from the baseline to the trough of the first negative wave and the b-wave, which originates in the ON-bipolar cells (Robson and Frishman, 1998), from the trough of the a-wave to the peak of the waveform, or when the a-wave was not present, from the baseline to the peak of the waveform.

Histology. After ERG recordings, we killed mice and then enucleated and immersion-fixed eyes in $4 \%$ paraformaldehyde for $30 \mathrm{~min}$. After rinsing with $0.1 \mathrm{M}$ phosphate buffer, the posterior eyecups were processed through a graded alcohol series and embedded in plastic resin (Embed 812/DER 736, Electron Microscopy Science) or paraffin. For plastic resin 
sections, we cut superior to inferior sections $(0.5 \mu \mathrm{m})$ of the retina bisecting the optic disc using an ultramicrotome (Reichert Ultracut, Leica) with a histo-diamond knife and stained with $1 \%$ aqueous toluidine blue (Sigma). Paraffin sections were cut with a rotary microtome in the superior-inferior plane, bisecting the optic nerve. All sections were imaged using a phase contrast microscope (Leica DM LB, Leica) at $20 \times$ power.

We quantified photoreceptor nuclei cells using an image analysis program (Image-Pro Plus 5.0; MediaCybernetics). We counted all of the nuclei in four regions of the outer nuclear layer $(\mathrm{ONL})$ : two superior and two inferior. Each region spanned $0.5 \mathrm{~mm}$ and was centered at either 0.5 $\mathrm{mm}$ or $1.0 \mathrm{~mm}$ from the optic nerve center. The counts from each region were averaged across three retinal sections for each eye. Photoreceptor nuclei from plastic and resin were normalized to the Dim + Inactive group separately and then averaged. For ANA-12 photoreceptor quantification, we embedded retinas in plastic resin and normalized to the Bright + Treadmill + Vehicle group.

Statistical analyses. We performed one- and two-way repeatedmeasures ANOVAs and Student's $t$ tests using commercial statistical analysis software (SigmaStat 3.5; Systat Software). Significance was set at $p<0.05$ for all analyses, and values are expressed as mean \pm SEM. We performed post hoc multiple comparisons using the Holm-Sidak method. For nonparametric data, ANOVA on ranks was performed. The reported $n$ is the total number of animals examined per group.

\section{Results}

\section{Aerobic exercise preserved retinal function with LIRD}

Treadmill training significantly preserved retinal function in mice exposed to toxic bright light. Bright light exposure greatly reduced retinal function (Fig. $1 A, B$ ), similar to previous reports (Noell et al., 1966; Organisciak and Vaughan, 2010). ERG waveforms from representative mice in each group at 2 weeks after light exposure showed larger amplitudes with exercise compared with inactivity (Fig. 1A). Within groups exposed to toxic bright light, mice undergoing treadmill training had significantly preserved a- and b-wave amplitudes compared with inactive mice at the brightest flash stimuli (Figure $1 C, D ; 0.8$ and $2.1 \log \mathrm{cd} \mathrm{s} / \mathrm{m}^{2}$; two-way repeated-measures ANOVA; a-wave: $F_{(3,239)}=14.896$, $p<0.001$; b-wave: $\left.F_{(3,239)}=8.759, p<0.001\right)$. Moreover, ERG aand $b$-wave amplitudes at the brightest flash intensity remained consistent between 1 and 2 weeks after light exposure, indicating that exercise sustained preservation over this period (Fig. 1B). Exercised mice exposed to dim light had a nonsignificant trend for greater maximum a- and b-wave amplitudes compared with inactive, dim light-exposed mice (Fig. 1B). We found no associations between the number of shocks and ERG amplitudes (data not shown). In addition, mice that ran on a treadmill without electric shock showed similar protective effects (data not shown).

\section{Aerobic exercise preserved photoreceptor cell counts with LIRD}

We examined the number of photoreceptor nuclei in the ONL of retinal sections from eyes collected 2 weeks after light exposure (Fig. 2). With dim light exposure, there were no benefits of exercise (Fig. $2 A, B$ ). However, after bright light exposure, the retinas of exercised mice maintained a thicker ONL of approximately six rows of photoreceptor nuclei and had preserved inner and outer segments (Fig. $2 E, F$ ) compared with inactive mice, which degenerated to approximately two rows of photoreceptor nuclei, with a complete loss of ONL organization and absence of photoreceptor outer segments (Fig. 2C,D). The number of photoreceptor nuclei in exercised mice exposed to bright light was significantly decreased at all retinal locations but significantly preserved by exercise (two-way repeated-measures ANOVA, main effect of treatment, $F_{(3,147)}=75.9 p<0.001$; Fig. $\left.2 G\right)$. Additionally, the summed photoreceptor nuclei in mice exposed to bright light was
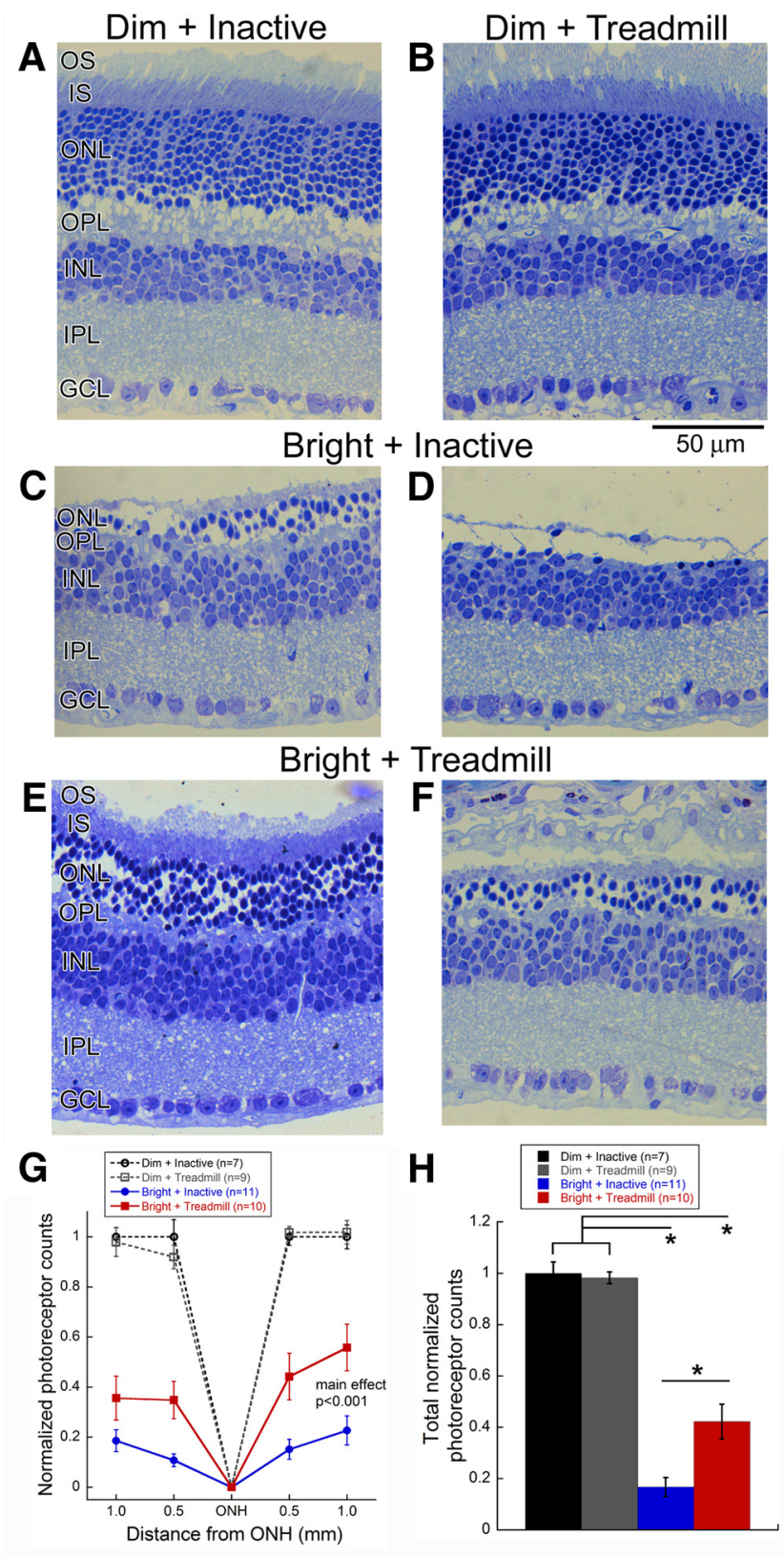

Figure 2. Aerobic exercise preserved photoreceptor structure after LIRD. Retinal micrographs from BALB/C mice exposed to Dim + Inactive $(\boldsymbol{A})$, Dim + Treadmill $(\boldsymbol{B})$, Bright + Inactive $(\boldsymbol{C}, \boldsymbol{D})$, or Bright + Treadmill $(\boldsymbol{E}, \boldsymbol{F})$. Images represent retinal sections taken $1.0 \mathrm{~mm}$ from the optic nerve. For the bright light-exposed groups, we presented micrographs showing the maximal $(\boldsymbol{C}, \boldsymbol{E})$ and minimal $(\boldsymbol{D}, \boldsymbol{F})$ number of photoreceptor nuclei for each group. Mice that received bright light and treadmill exercise treatment $(\boldsymbol{E}, \boldsymbol{F})$ had thicker outer nuclear layers, and outer and inner photoreceptor segments than those of the Bright + Inactive group $(\boldsymbol{C}, \boldsymbol{D})$. $\mathbf{G}$, The number of photoreceptors in exercised mice exposed to bright light was significantly decreased at all retinal locations but significantly preserved by exercise (two-way repeatedmeasures ANOVA, main effect of treatment, $\left.F_{(3,147)}=75.9, p<0.001\right)$. $\boldsymbol{H}$, Bright + Treadmill mice had significantly more total photoreceptor nuclei compared with Bright + Inactive mice (one-way ANOVA $F_{(3,36)}=78.3, p<0.001$ ). Holm-Sidak post hoc comparisons: ${ }^{*} p<0.001$. OS, Outer segments; IS, inner segments; OPL, outer plexiform layer; INL, inner nuclear layer; IPL, inner plexiform layer; $\mathrm{GCL}$, ganglion cell layer. Values are mean \pm SEM.

significantly greater with treadmill exercise versus inactivity (one-way ANOVA: $F_{(3,36)}=78.3, p<0.001$; Fig. $2 H$ ). We did not observe any significant differences in retinal morphology and number of photoreceptors between exercised and inactive mice exposed to dim light (Fig. 2A,B,G,H). Finally, we observed no 
A

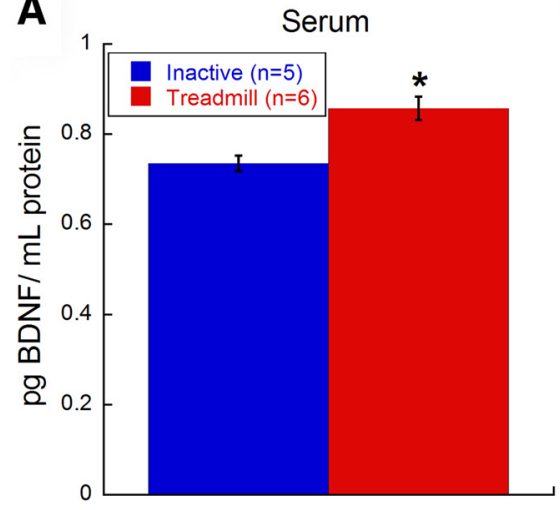

B

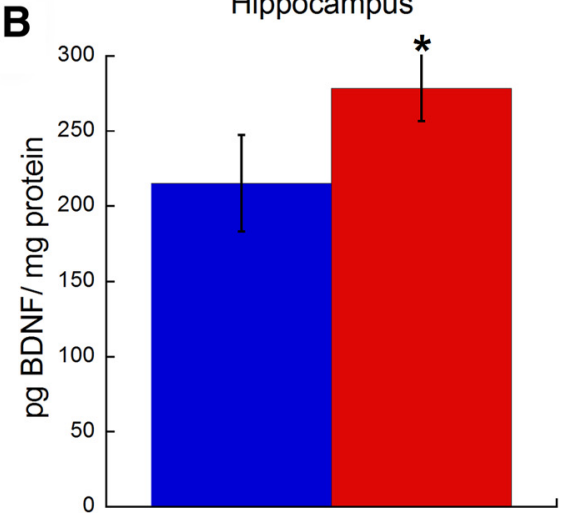

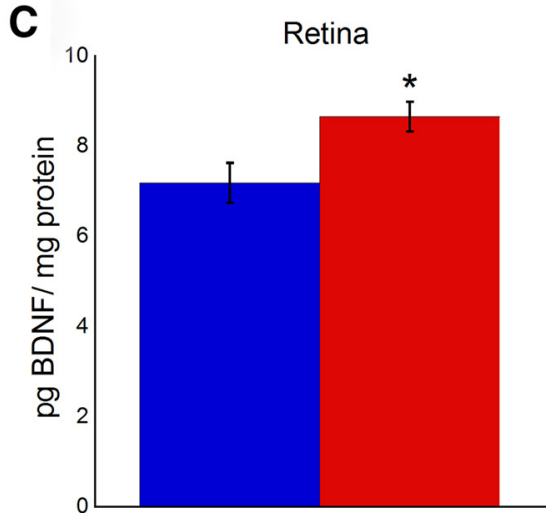

Figure 3. Aerobic exercise increases local and systemic BDNF protein levels. Naive BALB/C mice exercised on a treadmill had significantly greater BDNF protein levels in the (A) serum (Student's $t$ test, $\left.{ }^{*} p=0.003\right),(B)$ hippocampus (Student's $t$ test, $\left.{ }^{*} p=0.004\right)$, and $(\boldsymbol{C})$ retina (Student's $t$ test, ${ }^{*} p=0.024$ ) compared with inactive mice. Values are mean \pm SEM.

differences of inner retinal layer thickness between treatment groups.

\section{Aerobic exercise increased BDNF Protein Levels}

Serum BDNF protein levels were significantly increased with treadmill exercise relative to inactive mice (Student's $t$ test, $p=$ 0.003; Fig. 3A). Additionally, hippocampal BDNF protein levels in treadmill mice were significantly greater than inactive mice (Student's $t$ test, $p=0.004$; Fig. $3 B$ ). Retinal BDNF protein levels in treadmill mice were also significantly greater than BDNF protein levels in inactive mice (Student's $t$ test, $p=0.0239$; Fig. $3 C$ ), demonstrating that treadmill training increased retinal BDNF protein levels.

\section{Protective effects of exercise were blocked following treatment with a TrkB antagonist}

ANA-12 had no measureable effects on normal retinal function. Dim light-exposed mice treated with ANA-12 after treadmill exercise or inactivity showed similar photoreceptor (a-wave; Fig. $4 A$ ) and inner retinal (b-wave; Fig. $4 B$ ) function to Dim + Treadmill + Vehicle mice.

One week after toxic bright light exposure, exercised mice injected with ANA-12 had greatly reduced retinal function compared with vehicle-injected (representative ERG waveforms; Fig. 4C). Quantified a- and b-wave responses across ERG flash stimuli revealed that Treadmill + Vehicle mice had greater amplitudes while ANA-12 treatment significantly suppressed exercised-induced protection to the point of being statistically indistinguishable from nonexercised mice at the brightest flash intensities (Figure $4 D, E$; two-way repeated-measures ANOVA, $F_{(12,184)}=2.31, p=0.01$ and $F_{(12,184)}=2.29, p=0.01$, respectively).

Treatment with ANA-12 resulted in significantly fewer photoreceptor nuclei compared with vehicle treatment of exercised mice that had been exposed to toxic bright light (one-way ANOVA on Ranks; H $(3)=14.85, p=0.002$; Fig. $4 F)$. As with the functional analysis, treatment with ANA-12 resulted in nuclei counts that were statistically indistinguishable from nonexercised mice.

\section{Discussion}

In this study we tested the protective effects of aerobic exercise on the neural retina. We found that aerobic treadmill exercise performed 2 weeks before and 1 or 2 weeks after toxic bright light exposure protected retinal function and structure. Treadmill exercise also resulted in increased retinal BDNF protein levels. In- terestingly, treatment with a BDNF TrkB receptor antagonist blocked the protective effects of exercise and reduced the functional and structural benefits, suggesting an underlying mechanism for the observed beneficial effects.

Previously, only indirect evidence indicated any beneficial effects of exercise on the retina. An association study of 55-year-old distance runners showed reduced risk of age-related macular degeneration when running $>2 \mathrm{~km} / \mathrm{d}$ (Williams, 2009), suggesting potential benefit of exercise to retinal disease. A limitation of this study population is that the subjects had been recruited from a National Runners' Health Study, which suggests that these individuals were active and choosing healthy lifestyles that may reduce several risk factors. However, animal models have also suggested potential benefits of exercise to the retina. Environmental enrichment, which includes access to voluntary running wheels, slows retinal function loss in a mouse model of retinitis pigmentosa (Barone et al., 2012). Although no attempts were made in that study to isolate the possible protective effects of aerobic exercise on retinal function in the environmental enrichment model, our results suggest that aerobic exercise could play a significant role in protecting photoreceptors.

Aerobic exercise has been shown to increase hippocampal and serum levels of BDNF protein and RNA (Marais et al., 2009; Aguiar et al., 2011; Erickson et al., 2011; Gomez-Pinilla et al., 2011; Ke et al., 2011; Um et al., 2011; Quirié et al., 2012; Real et al., 2013). We found similar exercise-induced increases in BDNF levels in serum and hippocampus. Further, we demonstrated that aerobic exercise increased retinal levels of BDNF protein. Retinal BDNF may originate from the increased circulating levels in the serum crossing the retinal-blood barrier or exercise may have a more direct effect on retinal physiology that increases BDNF, such as increased blood flow (Okuno et al., 2006).

Treadmill running did not protect against LIRD in mice treated with ANA-12, a low-molecular weight heterocyclic compound shown to alter complex formation between BDNF and TrkB (Cazorla et al., 2011). Although the TrkB antagonist experiments implicate BDNF in the protective effects in the retina with exercise, it is not clear whether the duration or frequency of exercise is important because BDNF release in the serum and brain correlates with duration of exercise (Oliff et al., 1998; Berchtold et al., 2005; Rasmussen et al., 2009). Furthermore, in these studies, we were able to show an increase in BDNF protein after 9 consecutive days of running $(\sim 5.4 \mathrm{~km})$ and protective effects mediated by BDNF after only 2 weeks of preconditioning 
$(\sim 3 \mathrm{~km})$. Although the total distance that the mice ran was different, it is important to note that we found a protective effect for retinal function and structure with less exercise. Additional experiments are needed to determine the minimal amount of exercise needed to promote the BDNF response for protective effects in the retina and the source of retinal BDNF protein after exercise.

Previous studies have shown the positive impact of growth factors on retinal degenerative diseases, such as CNTF, bFGF, and BDNF (LaVail et al., 1992; Unoki and LaVail, 1994). Indeed, intravitreal injections of BDNF have been shown to protect against constant light exposure (LaVail et al., 1992; Ikeda et al., 2003) and reduce retinal damage after photodynamic therapy (Paskowitz et al., 2004). However, some of these growth factors produce unwanted side effects with exogenous delivery, are not beneficial across all retinal degenerative diseases, and require repeated invasive procedures for delivery (Lavail, 2005). Aerobic exercise offers a noninvasive approach to increase endogenous BDNF levels (Intlekofer and Cotman, 2013), which might serve to protect the retina or that could be used in combination with other therapies for combined effects.

BDNF and TrkB are present in developing and adult retina, including retinal ganglion cells and dopaminergic amacrine cells, across several species (Cellerino and Kohler, 1997). Additionally, BDNF and TrkB colocalize to green-red sensitive cone outer segments in the rat retina (Di Polo et al., 2000) and TrkB is expressed by several inner retinal cell types in mice (Rohrer et al. 1999). This study used scotopic ERGs to test for retinal function such that rod function was tested with dim stimuli and $\mathrm{rod} /$ cone function at the brightest flash stimuli. Because only bright stimuli showed significant differences between treadmill and inactive light-induced retinal degeneration mice, these data may suggest that cone function selectively benefits from exercise. However, it should also be noted that the histological images (Fig. 2) show preservation of rod inner and outer segments with exercise, which suggests some benefit to rods, commiserate with a known role for TrkB in rod photoreceptor development (Rohrer et al., 2003). Future studies should examine the potential benefit of aerobic exercise on cone function and morphology as preservation would provide the most efficacy for visual function.
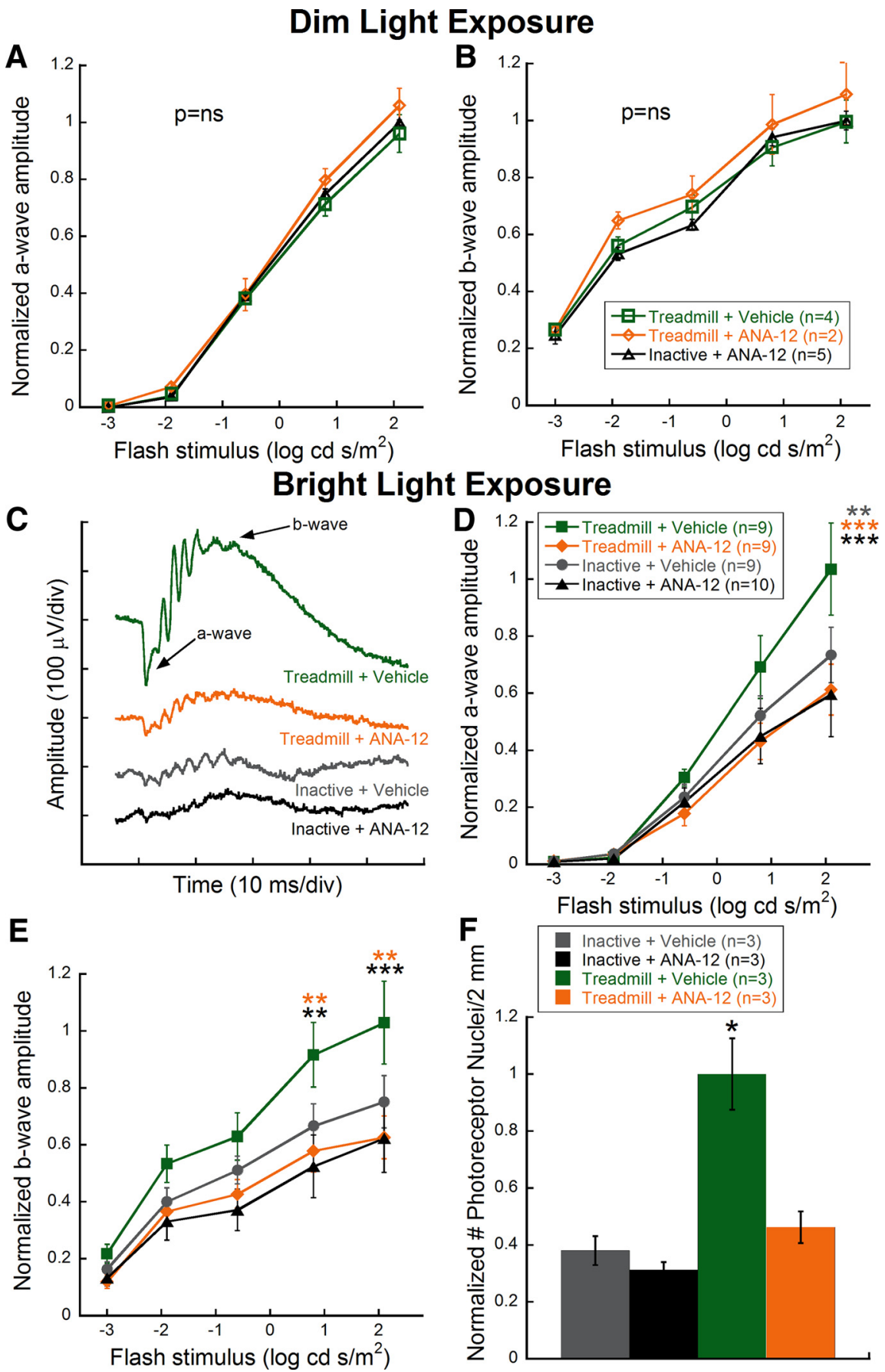

Figure 4. Treatment with the TrkB antagonist, ANA-12, eliminates protective effects of aerobic exercise on retinal degeneration. ANA-12 had no effect on normal photoreceptor $(\boldsymbol{A})$ and inner retinal $(\boldsymbol{B})$ function as measured by $E R G$ a- and b-wave amplitudes, respectively, in dim-exposed mice. $C$, Representative ERG waveforms from the brightest flash $(2.1 \mathrm{log}$ $\mathrm{cd} s / \mathrm{m}^{2}$ ) taken 1 week after bright light exposure illustrate that the Treadmill + ANA-12 group had reduced amplitude responses compared with Treadmill + Vehicle; arrows indicate a- and b-waves. $\boldsymbol{D}, \boldsymbol{E}$, Stimulus response curves for darkadapted a-wave $(\boldsymbol{D})$ and b-wave $(\boldsymbol{E})$ amplitudes for all groups at 1 week after light exposure. Bright + Treadmill + Vehicle-treated mice (green) showed significantly greater amplitudes at bright flash intensities compared with Bright + Treadmill + ANA-12 mice (orange) for the a-wave (tw0-way repeated-measures ANOVA; $F_{(12,184)}=2.31, p=0.01$ ) and b-wave $\left(F_{(12,184)}=2.29, p=0.01\right)$, indicating elimination of the protective effect of aerobic exercise using a BDNF trkB receptor antagonist. Bright + Treadmill + ANA-12, Bright + Inactive + Vehicle, and Bright + Inactive + ANA-12 groups had no significant differences. Holm-Sidak post hoc comparisons: ${ }^{*} p<0.05,{ }^{* *} p<0.01,{ }^{* *} p<0.001$. Significance differences between Bright + Treadmill + Vehicle and the color-coded treatment group. $\boldsymbol{F}$, Bright + Treadmill + Vehicle mice had significantly more total photoreceptor nuclei compared with Bright + Treadmill + ANA-12 mice and Bright + Inactive mice injected with either ANA-12 or vehicle (one-way ANOVA by ranks, $\mathrm{H}=14.85, p=0.002$ ). Values are mean \pm SEM. 
We have shown that aerobic exercise can directly benefit degenerating photoreceptors in the mouse model of light-induced retinal degeneration. Aerobic exercise is a noninvasive, inexpensive rehabilitative therapy that is not currently prescribed to patients with vision loss. Our findings provide motivation for further experiments on the efficacy of aerobic exercise for retinal degenerative diseases.

\section{References}

Aguiar AS Jr, Castro AA, Moreira EL, Glaser V, Santos AR, Tasca CI, Latini A, Prediger RD (2011) Short bouts of mild-intensity physical exercise improve spatial learning and memory in aging rats: involvement of hippocampal plasticity via AKT, CREB and BDNF signaling. Mech Ageing Dev 132:560-567. CrossRef Medline

Anderson BJ, Rapp DN, Baek DH, McCloskey DP, Coburn-Litvak PS, Robinson JK (2000) Exercise influences spatial learning in the radial arm maze. Physiol Behav 70:425-429. CrossRef Medline

Barone I, Novelli E, Piano I, Gargini C, Strettoi E (2012) Environmental enrichment extends photoreceptor survival and visual function in a mouse model of retinitis pigmentosa. PLoS One 7:e50726. CrossRef Medline

Berchtold NC, Chinn G, Chou M, Kesslak JP, Cotman CW (2005) Exercise primes a molecular memory for brain-derived neurotrophic factor protein induction in the rat hippocampus. Neuroscience 133:853-861. CrossRef Medline

Boatright JH, Moring AG, McElroy C, Phillips MJ, Do VT, Chang B, Hawes NL, Boyd AP, Sidney SS, Stewart RE, Minear SC, Chaudhury R, Ciavatta VT, Rodrigues CM, Steer CJ, Nickerson JM, Pardue MT (2006) Tool from ancient pharmacopoeia prevents vision loss. Mol Vis 12:1706-1714. Medline

Cazorla M, Prémont J, Mann A, Girard N, Kellendonk C, Rognan D (2011) Identification of a low-molecular weight TrkB antagonist with anxiolytic and antidepressant activity in mice. J Clin Invest 121:1846-1857. CrossRef Medline

Cellerino A, Kohler K (1997) Brain-derived neurotrophic factor/ neurotrophin- 4 receptor TrkB is localized on ganglion cells and dopaminergic amacrine cells in the vertebrate retina. J Comp Neurol 386:149160. CrossRef Medline

Chaddock L, Erickson KI, Prakash RS, VanPatter M, Voss MW, Pontifex MB, Raine LB, Hillman CH, Kramer AF (2010) Basal ganglia volume is associated with aerobic fitness in preadolescent children. Dev Neurosci 32: 249-256. CrossRef Medline

Cruise KE, Bucks RS, Loftus AM, Newton RU, Pegoraro R, Thomas MG (2011) Exercise and Parkinson's: benefits for cognition and quality of life. Acta Neurol Scand 123:13-19. CrossRef Medline

Di Polo A, Cheng L, Bray GM, Aguayo AJ (2000) Colocalization of TrkB and brain-derived neurotrophic factor proteins in green-red-sensitive cone outer segments. Invest Ophthalmol Vis Sci 41:4014-4021. Medline

Erickson KI, Voss MW, Prakash RS, Basak C, Szabo A, Chaddock L, Kim JS, Heo S, Alves H, White SM, Wojcicki TR, Mailey E, Vieira VJ, Martin SA, Pence BD, Woods JA, McAuley E, Kramer AF (2011) Exercise training increases size of hippocampus and improves memory. Proc Natl Acad Sci U S A 108:3017-3022. CrossRef Medline

Filippin NT, da Costa PH, Mattioli R (2010) Effects of treadmill-walking training with additional body load on quality of life in subjects with Parkinson's disease. Rev Bras Fisioter 14:344-350. CrossRef Medline

Gomez-Pinilla F, Zhuang Y, Feng J, Ying Z, Fan G (2011) Exercise impacts brain-derived neurotrophic factor plasticity by engaging mechanisms of epigenetic regulation. Eur J Neurosci 33:383-390. CrossRef Medline

Griffin ÉW, Mullally S, Foley C, Warmington SA, O’Mara SM, Kelly AM (2011) Aerobic exercise improves hippocampal function and increases BDNF in the serum of young adult males. Physiol Behav 104:934-941. CrossRef Medline

Hood DC, Birch DG (1990) A quantitative measure of the electrical activity of human rod photoreceptors using electroretinography. Vis Neurosci 5:379-387. CrossRef Medline

Ikeda K, Tanihara H, Tatsuno T, Noguchi H, Nakayama C (2003) Brainderived neurotrophic factor shows a protective effect and improves recovery of the ERG b-wave response in light-damage. J Neurochem 87:290-296. CrossRef Medline

Intlekofer KA, Cotman CW (2013) Exercise counteracts declining hip- pocampal function in aging and Alzheimer's disease. Neurobiol Dis 57: 47-55. CrossRef Medline

Ke Z, Yip SP, Li L, Zheng XX, Tong KY (2011) The effects of voluntary, involuntary, and forced exercises on brain-derived neurotrophic factor and motor function recovery: a rat brain ischemia model. PLoS One 6:e16643. CrossRef Medline

Lavail MM (2005) Survival factors for treatment of retinal degenerative disorders: preclinical gains and issues for translation into clinical studies. Retina 25:S25-S26. CrossRef Medline

LaVail MM, Unoki K, Yasumura D, Matthes MT, Yancopoulos GD, Steinberg RH (1992) Multiple growth factors, cytokines, and neurotrophins rescue photoreceptors from the damaging effects of constant light. Proc Natl Acad Sci U S A 89:11249-11253. CrossRef Medline

Marais L, Stein DJ, Daniels WM (2009) Exercise increases BDNF levels in the striatum and decreases depressive-like behavior in chronically stressed rats. Metab Brain Dis 24:587-597. CrossRef Medline

McCrate ME, Kaspar BK (2008) Physical activity and neuroprotection in amyotrophic lateral sclerosis. Neuromolecular Med 10:108-117. CrossRef Medline

Mocko JA, Kim M, Faulkner AE, Cao Y, Ciavatta VT, Pardue MT (2011) Effects of subretinal electrical stimulation in mer-KO mice. Invest Ophthalmol Vis Sci 52:4223-4230. CrossRef Medline

Noell WK, Walker VS, Kang BS, Berman S (1966) Retinal damage by light in rats. Invest Ophthalmol 5:450-473. Medline

Okuno T, Sugiyama T, Kohyama M, Kojima S, Oku H, Ikeda T (2006) Ocular blood flow changes after dynamic exercise in humans. Eye 20:796800. CrossRef Medline

Oliff HS, Berchtold NC, Isackson P, Cotman CW (1998) Exercise-induced regulation of brain-derived neurotrophic factor (BDNF) transcripts in the rat hippocampus. Brain Res Mol Brain Res 61:147-153. CrossRef Medline

Organisciak DT, Vaughan DK (2010) Retinal light damage: mechanisms and protection. Prog Retin Eye Res 29:113-134. CrossRef Medline

Paskowitz DM, Nune G, Yasumura D, Yang H, Bhisitkul RB, Sharma S, Matthes MT, Zarbin MA, Lavail MM, Duncan JL (2004) BDNF reduces the retinal toxicity of verteporfin photodynamic therapy. Invest Ophthalmol Vis Sci 45:4190-4196. CrossRef Medline

Penn RD, Hagins WA (1969) Signal transmission along retinal rods and the origin of the electroretinographic a-wave. Nature 223:201-204. CrossRef Medline

Ploughman M, Granter-Button S, Chernenko G, Attwood Z, Tucker BA, Mearow KM, Corbett D (2007) Exercise intensity influences the temporal profile of growth factors involved in neuronal plasticity following focal ischemia. Brain Res 1150:207-216. CrossRef Medline

Quirié A, Hervieu M, Garnier P, Demougeot C, Mossiat C, Bertrand N, Martin A, Marie C, Prigent-Tessier A (2012) Comparative effect of treadmill exercise on mature BDNF production in control versus stroke rats. PLoS One 7:e44218. CrossRef Medline

Radák Z, Kaneko T, Tahara S, Nakamoto H, Pucsok J, Sasvári M, Nyakas C, Goto S (2001) Regular exercise improves cognitive function and decreases oxidative damage in rat brain. Neurochem Int 38:17-23. CrossRef Medline

Rasmussen P, Brassard P, Adser H, Pedersen MV, Leick L, Hart E, Secher NH, Pedersen BK, Pilegaard H (2009) Evidence for a release of brain-derived neurotrophic factor from the brain during exercise. Exp Physiol 94:10621069. CrossRef Medline

Real CC, Ferreira AF, Chaves-Kirsten GP, Torrão AS, Pires RS, Britto LR (2013) BDNF receptor blockade hinders the beneficial effects of exercise in a rat model of Parkinson's disease. Neuroscience 237:118-129. CrossRef Medline

Remé CE, Grimm C, Hafezi F, Iseli HP, Wenzel A (2003) Why study rod cell death in retinal degenerations and how? Doc Ophthalmol 106:25-29. CrossRef Medline

Robson JG, Frishman LJ (1998) Dissecting the dark-adapted electroretinogram. Doc Ophthalmol 95:187-215. CrossRef Medline

Rohrer B, Ogilvie JM (2003) Retarded outer segment development in TrkB knockout mouse retina organ culture. Mol Vis 9:18-23. Medline

Rohrer B, Korenbrot JI, LaVail MM, Reichardt LF, Xu B (1999) Role of neurotrophin receptor TrkB in the maturation of rod photoreceptors and establishment of synaptic transmission to the inner retina. J Neurosci 19:8919-8930. Medline

Sabatier MJ, Redmon N, Schwartz G, English AW (2008) Treadmill training 
promotes axon regeneration in injured peripheral nerves. Exp Neurol 211:489-493. CrossRef Medline

Sabatier MJ, To BN, Nicolini J, English AW (2011) Effect of axon misdirection on recovery of electromyographic activity and kinematics after peripheral nerve injury. Cells Tissues Organs 193:298-309. CrossRef Medline

Spaeth AM, Kanoski SE, Hayes MR, Grill HJ (2012) TrkB receptor signaling in the nucleus tractus solitarius mediates the food intake-suppressive effects of hindbrain BDNF and leptin. Am J Physiol Endocrinol Metab 302:E1252-E1260. CrossRef Medline

Turner PV, Albassam MA (2005) Susceptibility of rats to corneal lesions after injectable anesthesia. Comp Med 55:175-182. Medline

Um HS, Kang EB, Koo JH, Kim HT, Jin L, Kim EJ, Yang CH, An GY, Cho IH, Cho JY (2011) Treadmill exercise represses neuronal cell death in an aged transgenic mouse model of Alzheimer's disease. Neurosci Res 69: 161-173. CrossRef Medline

Unoki K, LaVail MM (1994) Protection of the rat retina from ischemic injury by brain-derived neurotrophic factor, ciliary neurotrophic factor, and basic fibroblast growth factor. Invest Ophthalmol Vis Sci 35:907-915. Medline van Praag H, Christie BR, Sejnowski TJ, Gage FH (1999) Running enhances neurogenesis, learning, and long-term potentiation in mice. Proc Natl Acad Sci U S A 96:13427-13431. CrossRef Medline

Vassoler FM, White SL, Schmidt HD, Sadri-Vakili G, Pierce RC (2013) Epigenetic inheritance of a cocaine-resistance phenotype. Nat Neurosci 16: 42-47. CrossRef Medline

Vessal M, Darian-Smith C (2010) Adult neurogenesis occurs in primate sensorimotor cortex following cervical dorsal rhizotomy. J Neurosci 30: 8613-8623. CrossRef Medline

Vreugdenhil A, Cannell J, Davies A, Razay G (2012) A community-based exercise programme to improve functional ability in people with Alzheimer's disease: a randomized controlled trial. Scand J Caring Sci 26:12-19. CrossRef Medline

Williams PT (2009) Prospective study of incident age-related macular degeneration in relation to vigorous physical activity during a 7-year followup. Invest Ophthalmol Vis Sci 50:101-106. CrossRef Medline

Wood K, Wilhelm JC, Sabatier MJ, Liu K, Gu J, English AW (2012) Sex differences in the effectiveness of treadmill training in enhancing axon regeneration in injured peripheral nerves. Dev Neurobiol 72:688-698. CrossRef Medline 